\title{
STUDI TAFSIR QS. AL-NISÂ' AYAT 3 TENTANG KEABSAHAN POLIGAMI
}

\author{
Muhammad Zulianto \\ Universitas Hasyim Asy'ari Jombang, Indonesia \\ E-mail: zuliantomuhammad81@yahoo.com
}

\begin{abstract}
In Islamic Law monogamy and polygamy got a legality. Interpretation about letter al-Nisâ' clause 3 is basically talking about the principle of monogamy and terms in order to make polygamy. Husband is not allowed to practice polygamy if they worry can not do justice. Referring to lafaz, shartiyyah 'wa in khiftum' which is also affirmed in subsequent lafaz, namely 'allâ ta'dilu'. Exegetes requires legitimacy of polygamy mentioned in the letter al-Nisâ' clause 3 if the husband could do justice. Generaly this review explain about the Interpretation of letter al-Nisâ' clause 3 according expert of tafseer. But more than its there are many analysis from fikih, ordinance as like UU Perkawinan 1974, social fenomena, feminism analyst, and the methodology of exegesis. Among the selective opinion judicial formally prove the husband can be fair or not is al-Marâgi with additional terms likes if; the wife is barren; the husband has a high sexual desire; the husband has enough assets to cover all the needs of the family; and if the number of women more than men, which may occur as a result of the war. Thats are capacity requirement for husband want to get the legality of polygamy
\end{abstract}

Kaywords: Interpretation Studies, al-Nisâ' Clause 3, Legality of Polygamy 


\section{Pendahuluan}

Poligami merupakan salah satu persoalan dalam perkawinan yang sering dibicarakan. Satu sisi poligami ditolak dengan berbagai macam arugmentasi baik yang bersifat normatif, psikologis bahkan selalu dikaitkan dengan ketidakadilan gender. Pada sisi lain, poligami dikampanyekan karena sebagai salah satu alternatif untuk menyelesaikan fenomena selingkuh dan prostitusi. ${ }^{1}$

Adapaun ketentuan lain yang mengatur tentang poligami dapat kita simak dalam UU No.1 Tahun 1974, dan PP No. 9 Tahun 1975. Keduanya secara garis besar mengatur tentang prosedur permohonan izin poligami. Di antara yang harus diperiksa oleh pengadilan setelah permohonan diajukan adalah alasan-alasan untuk berpoligami, persetujuan dari isteri baik secara lisan maupun tulisan, kemampuan menjamin kebutuhan hidup yang disertai bukti lampiran-lampiran, serta bukti pernyataan untuk berlaku adil.

Namun demikian Islam tidak menutup rapat seorang laki-laki muslim kawin dengan empat orang perempuan dalam satu waktu apabila ia sanggup memelihara dan berlaku adil terhadap isteri-isterinya dalam soal nafkah, tempat tinggal, dan pembagian waktu. ${ }^{2}$

Kompilasi Hukum Islam (KHI) sebagai fikih bernuansa keindonesiaan yang dijadikan pedoman oleh hakim-hakim di Pengadilan Agama telah memberi aturan tentang syarat beristeri lebih dari saorang. Di antara aturan tersebut adalah tentang jumlah isteri, syarat utama suami yang akan beristeri lebih dari satu, larangan beristeri lebih dari seorang, dan prosedur permohonan izin sesuai hukum yang berlaku.

Syarat utama yang disebutkan dalam KHI Bab IX Pasal 55 Ayat 2 untuk berpoligami adalah suami harus mampu berlaku adil terhadap isteri-isteri dan anak-anaknya. Konsekuensi hukum dari syarat utama tersebut adalah diperbolehkannya suami beristeri lebih dari satu dan larangan jika tidak mampu berlaku adil terhadap isteri-isteri dan anakanak.

Yang termaktub dalam KHI berdasar atas tafsir Al-Qur'an dalam QS. Al-Nisa: 03 yang secara eksplisit memberi syarat pokok terhadap suami untuk berlaku adil. Adapaun tafsir-tafsir diskursus tentang adil dalam surat QS. Al-Nisa: 03 sebagai syarat berpoligami akan dibahas lebih lanjut dalam artikel ini. Sehingga dapat dirumuskan; apa syarat keabsahan

\footnotetext{
${ }^{1}$ Amir Nuruddin dan Azhari Tarigan, Hukum Perdata Islam di Indonesia, (Jakarta: Perdana Media, 2004), 156.

${ }^{2}$ H. S. A. Al-Hamdani, Risalah Nikah, (Jakarta: Pustaka Amani), 38.
} 
poligami di dalam Al-Qur'an?; dan apa pula pengaruh metodologi penafsiran surat QS. Al-Nisa: 03 terhadap produk tafsir dari para mufassir?

\section{Ayat-Ayat Tentang Poligami}

Untuk membahas poligami, maka perlu adanya pembahasan ayat-ayat yang menjelaskan tentang hal tersebut. Dalam Al-Qur'an ayat yang menjelaskan tentang poligami hanya ada pada QS. Al-Nisa: 03, yaitu:
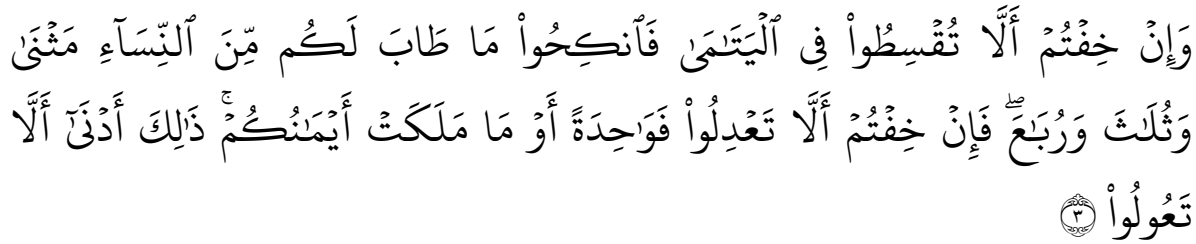

Artinya: "Dan jika kamu takut tidak akan dapat berlaku adil terhadap (hakbake) perempuan yang yatim (bilamana kamu mengawininya), maka kawinilah wanita-wanita (lain) yang kamu senangi: dua, tiga atau empat. Kemudian jika kamu takut tidak akan dapat berlaku adil, maka (kawinilab) seorang saja, atau budak-budak yang kamu miliki. Yang demikian itu adalah lebih dekat kepada tidak berbuat aniaya."

Pada dasarnya ayat tersebut adalah ayat yang menjelaskan tentang seseorang yang merawat anak yatim (menjadi walinya), dan menikahinya kemudian ditakutkan akan adanya ketidakadilan terhadap hak-hak yang dimiliki anak yatim tersebut, maka seorang wali atau orang yang menikahi anak yatim disuruh untuk menikahi orang lain (berpoligami), dengan harapan harta anak yatim yang sudah dinikahi tersebut tidak diselewengkan. Hal ini sesuai dengan beberapa sebab-sebab turunnya ayat tersebut, ayat tersebut turun dikarenakan ada beberapa sahabat yang menikahi anak yatim akan tetapi dalam hal nafkah dan kontribusi harta milik anak yatim tersebut suami tidak berlaku adil. ${ }^{3}$

Selain alasan di atas, Syaikh al-Zamakhṣârî dalam karyanya menjelaskan bahwasanya ayat tersebut turun dikarenakan untuk membatasi jumlah isteri. Pembatasan ini bertujuan untuk menanggulangi adanya ketidakadilan terhadap isteri, apabila isteri terlalu banyak. ${ }^{4}$

Ada beberapa riwayat yang menjelaskan tentang turunnya ayat tersebut. Untuk mengetahui sebab-sebab turunnya ayat di atas, maka

\footnotetext{
3 Muhammad 'Ali al-Ṣâbûnî, Rawai'u al-Bayân, Jakarta: Dâr al-Kutûb al-Islâmiyyah, 1999), vol. I, 298.

${ }^{4}$ Mạ̣mûd bin 'Umar bin Muhammad al-Zamakhsarî, Tafsîr al-Kashshâf, (Beirut: Dâr Kutûb al-'Ilmiyyah, 2006), Vol. I, 457.
} 
perlu untuk mengetahui beberapa riwayat yang menjelaskan turunnya ayat tersebut.

\section{Asbâb al-Nuzûl Ayat Tentang Poligami}

Ada tiga riwayat yang berbeda yang menjelaskan tentang sebab turunnya ayat di atas, keduanya diriwayatkan oleh Sayyidah 'Âisyah ra.:

Pertama, bahwasanya diriwayatkan ada seorang laki-laki dari gatafân memelihara anak yatim dan memegang harta kekayaan anak yatim tersebut, saat anak yatim tersebut balig, dia meminta hartanya, akan tetapi laki-laki tersebut mencegahnya, akhirnya anak yatim tersebut mengadu kepada nabi dan turunlah ayat tersebut. ${ }^{5}$

Kedua, ayat tersebut turun dikarenakan ada seorang laki-laki yang memelihara anak yatim dan menikahinya, dan anak yatim tersebut memiliki harta, akan tetapi anak yatim tersebut tidak diberi nafkah sama sekali oleh laki-laki tersebut, sehingga turunlah ayat 3 surat al-Nisâ' ${ }^{6}$

Kedua, riwayat yang menjelaskan tentang sebab turunnya ayat tersebut diriwayatkan oleh Imam Bukhârî dari 'Urwah bin Zubair, bahwasanya 'Urwah bertanya kepada 'Âisyah tentang ayat فَإِنْ خِفْتُمْ أَلََّ تَعْدِلُو yang dijawab oleh 'Âisyah: ayat tersebut diturunkan berkaitan dengan perempuan yatim yang diperlihara oleh walinya. Tetapi kemudian harta dan kecantikan perempuan yatim itu menarik hati si wali. Tetapi si wali itu ternyata tidak berlaku adil. Dia tidak mau memberi maskawin sebagaimana yang diberikan suami kepada isterinya yang setara. Ayat ini mencegah mereka berbuat demikian dan memerintahkan mereka untuk menikahi perempuan lain. ${ }^{7}$

Dari beberapa riwayat di atas, asumsi penulis adalah ayat tersebut turun berkenaan dengan adanya keadilan terhadap seorang perempuan yatim, apabila anak yatim tersebut dinikahi oleh orang yang memeliharannya dan memagang harta kekayannya. Bukan berarti ayat tersebut memerintahkan menikahi lebih dari satu orang perempuan tanpa adanya keadilan.

\section{Tafsir Per-lafadz Ayat Poligami}

Untuk dapat memahami ayat di atas, maka perlu untuk mengetahui kata kunci ayat tersebut. Selain itu juga perlu adanya penafsiran setiap

\footnotetext{
${ }^{5}$ Muhammad 'Ali al-Ṣâbûnî, Rawai'u al-Bayân..........., 298

${ }^{6}$ Muhammad 'Ali al-Ṣ̂bûnî, Rawai'u al-Bayân..........., 298.

${ }^{7}$ Muhammad 'Ali al-Ṣâbûnî, Rawai'u al-Bayân..........., 299.
} 
lafadz dari ayat tersebut. Adapun beberapa kata kunci yang perlu difahami dari ayat diatas adalah sebagai berikut:

lafadz tersebut merupakan shartiyyah, yang dimaksud khawatir di sini adalah, khawatir tidak dapat berlaku adil dalam mahar dan nafkah terhadap isteri. ${ }^{8}$

فَأْنكِحُواْ مَا طَابَ لَكُم lafadz tersebut merupakan jawab dari lafadz sebelumnya. Pada lafadaz tersebut yang perlu digaris bawahi adalah lafadz L. Dalam ilmu nahwu Lo adalah isim mausûl yang dikhususkan untuk sesuatu yang tidak berakal. Akan tetapi pada ayat ini, o bermakna manusia. Menanggapi hal ini imam Qurtûbî memberi beberapa jawaban:

a) Bahwasanya lafadz من dan lo terkadang saling berganti posisi, maksudnya adalah terkadang L mausûl bermakna sesuatu yang berakal seperti contoh وَأْلََمَآعِ وَمَا بَنَنَهَا من mausûl bedangkanakna sesuatu yang tidak berakal seperti contoh:

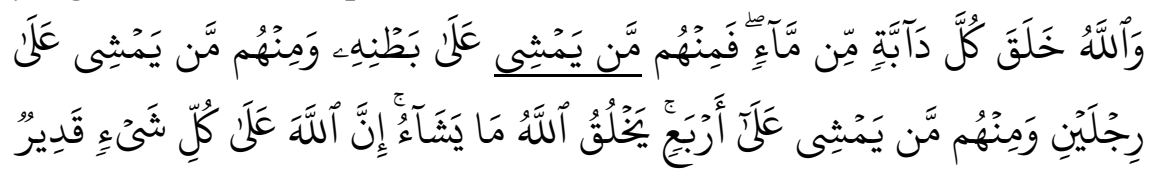

Adapun lafadz lo pada ayat 3 surat al-Nisâ' adalah diperuntukkan untuk sesuatu yang berakal yakni menunjukkan arti perempuan, hal ini dapat diketahui karena setelah lafadz o ada lafadz مِّنَ ألنََِّآِ di mana lafadz tersebut menjelaskan lafadz yang masih samar.

b) Lafadz L pada ayat diatas menurut ahli basrah diperuntukkan untuk beberapa sifat. Lafadz L pada poin ini diartikan sebagai sesuatu yang halal.

c) Menurut sebagian ulama lafadz $L_{0}$ pada ayat ini menjadi z̧arâf.

d) Menurut Imam Farrâ' Lo pada ayat ini adalah masdâr.

lafadz tersebut merupakan persyaratan dari adanya poligami. Dari sini kemudian para mufassir memberi keterangan bahwa bagi seseorang yang merasa tidak akan dapat berlaku adil terhadap isteri-

8 Muḥammad al-Aṇ̦arî al-Quṛtûbî, al-Jâmi' li Abkâm al-Qur'ân, (Beirut: Dâr Ihyya' alTurâth al-'Arabî , 2002), 12. 
isterinya, maka tetaplah untuk melakukan monogami. ${ }^{9}$ Sedangkan menurut M. Quraish Shihab kata al-'Adlu dan al-Qistu dalam bahasa indonesia memiliki kesamaan arti yakni adil. Akan tetapi ada sebagian ulama yang memberi perbedaan pada kedua kata tersebut. Yakni al-'Adlu adalah berlaku baik terhadap orang lain maupun diri sendiri, akan tetapi keadilan itu dapat tidak menyenangkan salah satu pihak. Sedangkan al-Qistu adalah berlaku adil antara dua orang atau lebih, dan keadilan yang menjadikan keduanya senang. Akan tetapi, karena kedua kata tersebut berada pada barisan kalimat yang memiliki konteks yang berbeda, maka makna keduanya berbeda pula maksudnya. Al-Qistu yang dimaksud berada pada kalimat $:^{10}$

Artinya: "Dan jikea kamu takut tidak akan dapat berlaku adil..."

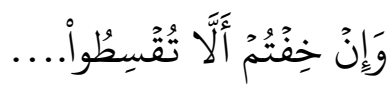

Adil yang dimaksud di sini adalah adil dalam bidang material, hal ini didasarkan pada surat al-Nisâ' ayat $4:^{11}$

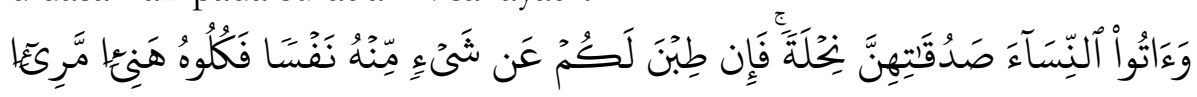

Artinya: "Berikanlah maskawin (mahar) kepada wanita (yang kamu nikahi) sebagai pemberian dengan penub kerelaan. Kemudian jïka mereka menyerabkan kepada kamu sebagian dari maskawin itu dengan senang hati, maka makanlah (ambillah) pemberian itu (sebagai makanan) yang sedap lagi baik akibatnya."

Selain ayat di atas, ayat yang menjadi dasar bahwa keadilan di dalam berpoligami bukanlah keadailan dalam inmaterial seperti cinta, kasih sayang, perasaan adalah surat al-Nisâ' ayat $129:^{12}$

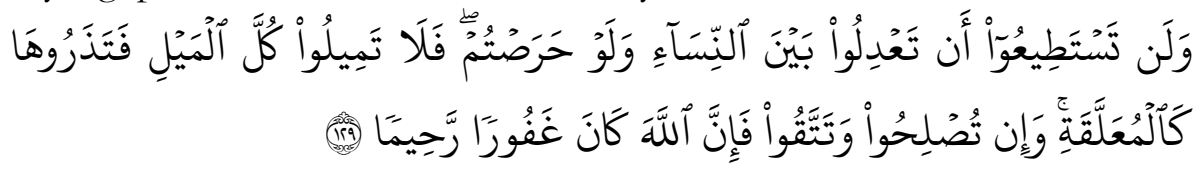

Artinya: "Dan kamu sekali-kali tidak akan dapat berlaku adil di antara isteriisteri(mu), walaupun kamu sangat ingin berbuat demikian, karena itu

\footnotetext{
${ }^{9}$ Muḥammad Zamakhsarî, Tafsir Al-Kashshâf, (Beirut: Dâr al-Kutûb al-'Ilmiyah, 2006), vol. I, 458.

10 M. Quraish Shihab, Tafsir al-Misbab; Pesan, Kesan dan keserasian al-Qur'an, (Jakarta: Lentera Hati, 2006), Vol. II, 338.

${ }^{11}$ M. Quraish Shihab, Wawasan Al-Qur'an, (Bandung: Mizan, 1999), 201.

${ }^{12}$ M. Quraish Shihab, Wawasan Al-Qur'an....., 201.
} 
janganlah kamu terlalu cenderung (kepada yang kamu cintai), sehingga kamu biarkan yang lain terkatung-katung. Dan jika kamu mengadakan perbaikan dan memelibara diri (dari kecurangan), maka sesunggubnya Allah Maba Pengampun lagi Maha Penyayang."

Dari keterangan lafadz-lafadz di atas, maka dapat diketahui bahwa sayarat dalam berpoligami di dalam Al-Qur'an hanya ada satu yakni berlaku adil terhadap isteri-isterinya. Yang dimaskud adil di sini adalah adil dalam segi cinta, nafkah, persetubuhan, dan pergaulan. ${ }^{13}$

Dalam hal ini al-Marâgî menambahkan bahwa, selain adil ada beberapa syarat untuk dapat melakukan poligami: ${ }^{14}$

Pertama, Karena isteri mandul, sedangkan salah satu dari suami isteri tersebut sangat mengharapkan keturunan.

Kedua, Apabila suami memiliki hasrat seks yang tinggi, sedangkan isteri tidak akan mampu melayani hasrat seks suami tersebut.

Ketiga, Jika suami memiliki harta yang banyak untuk membiayai semua kebutuhan keluarga, yang dimaksud kebutuhan keluarga di sini adalah kebutuhan isteri dan anak-anak.

Keempat, Jika jumlah wanita lebih banyak daripada pria, yang mungkin terjadi akibat perang, yang mana dari peperangan tersebut berakibat pada banyaknya janda dan anak yatim yang perlu untuk dilindungi, maka dalam alasan ini diperbolehkan untuk melakukan poligami.

\section{Syarat Poligami Dalam Pandangan Fikih}

Di atas sudah dijelaskan bahwa di dalam Al-Qur'an keabsahan atau syarat dalam melakukan poligami adalah adil. Dari sini kemudian ulama fikih membagi keadilan dalam berpoligami dalam beberapa pembagian:

1) Adil terhadap pembagian giliran

Dalam hal keadilan pembagian giliran, banyak dijelaskan dalam literatur fikih bahwa untuk membagi giliran terhadap isteri, suami harus melakukan pembagian yang setara, bahkan dijelaskan bahwa meskipun isteri dalam keadaan $u d h u r$ haid atau sakit, suami harus tetap memberinya giliran. ${ }^{15}$ Dalam hal jimâ' tidak wajib disamakan banyaknya, akan tetapi disunnahkan. ${ }^{16}$

\footnotetext{
${ }^{13}$ Muhammad al-Aṇsarî al-Qurtûbî, al-jâmi' li Aḅkâm al-Qur'ân....., 18.

${ }^{14}$ Muṣtafâ al-Marâgî, Tafsîr al-Marâgî, (Mesir: t.t.p, 1974), Vol. IV, 328.

15 Muhammad Shạtâ al-Dimyạtî al-Bakrî, I'anah al-Tâlibîn, (Beirut: Dâr al-Kutûb al'Ilmiyah, 2006), 618.

${ }^{16}$ Muhammad Shạtâ al-Dimyạtî al-Bakrî, I'anah al-Tâlibîn......, 618.
} 
Bila seorang laki-laki menikahi seorang mempunyai isteri lebih dari satu, dan salah satunya adalah seorang gadis. Sedangkan si gadis tersebut memiliki hak untuk menuntut suaminya agar pada permulaan nikahnya si gadis diberi giliran selama tujuh malam. Berbeda dengan janda, hak bagi janda untuk menuntuk suaminya hanya terbatas selama tiga hari tiga malam. Dan setelah itu barulah diatur giliran dengan cara adil. ${ }^{17}$

Adapun dalam pembagian giliran suami harus memiliki tiga syarat. ${ }^{18}$ Pertama, berakal. Kedua, adalah suami harus sudah dalam keadaan baligh, dan memungkinkan untuk melakukan persetubuhan. Maka bagi suami yang masih kecil belum memiliki kewajiban untuk melakukan pembagian giliran, dikarenakan masih belum mampu melakukan jïmâ.

Ketiga, adalah isteri tidak dalam keadaan nushûz. Apabila isteri sedang dalam keadan nushîz. maka bagi suami tidak wajib untuk melakukan pembagian giliran baginya.

Dan juga tidak menggugurkan kewajiban suami apabila ada sesuatu yang dapat menghalangi untuk melakukan persetubuhan, seperti haidh, nifas dan sakit. Atau perkara yang menghalangi tersebut datang dari suami seperti, impoten, dikebiri atau sakit. Tidak adanya pengguguran ini dikarenakan tujuan dari adanya pembagian giliran adalah untuk ketentraman bukan untuk melakukan jimâ. ${ }^{19}$

2) Adil atas tempat tinggal

Salah satu kewajiban seorang suami atas isteri adalah menyediakan tempat tinggal yang layak. Tidak terkecuali bagi suami yang memiliki banyak isteri. Hal ini bertujuan untuk keamanan dan kenyamanan isteri ketika suami bepergian. Penyediaan rumah terhadap isteri tidak diharuskan untuk membeli, diperbolehkan dengan cara menyewa atau meminjam. Begitu juga apabila isteri sudah terbiasa menggunakan pembantu rumah tangga maka suami wajib menyediakannya. ${ }^{20}$

Dalam hal penyediaan atas tempat tinggal, suami tidak boleh mengumpulkan isteri-isterinya dalam satu rumah, kecuali apabila hal

17 'Abdullâh bin Hijâzî, Hashiyah al-Sharqâwî, (Beirut: Dâr al-Kutub Al-'Ilmiyah, 2005), Vol. IV, 10.

18 'Abdurrahmân al-Juzairî, Fiqh 'Alâ al-Madzâabib al-Arba'ah, (Beirut: Dâr al-Fikr, 2008), Vol. IV, 183.

19 Abdurraḥmân al-Juzairî, Fiqh 'Alâ al-Madžâhib al-Arba'ah....., 183.

20 Zainuddîn bin 'Abdu al-'Azîz al-Malibarî, Fațhu al-Mu'în, (Surabaya: al-Hidâyah, 1993), 233. 
tersebut mendapat persetujuan dari para isteri, maka mengumpulkan isteri-isteri dalam satu rumah diperbolehkan. ${ }^{21}$

3) Adil atas biaya hidup dan pakaian

Dalam hal pembiyaan suami terhadap isteri dalam hal pakaian sama seperti halnya kewajiban dalam hal pembagian giliran, dalam hal ini suami tidak wajib menyamakan pakaian dan biaya hidup para isteri. Akan tetapi suami wajib memberi nafkah yang sama dengan keadaan suaminya. Maka, apabila suami memberi nafkah dengan kadar yang tidak sama dalam keadaanya maka berhukum haram. ${ }^{22}$

\section{Pengaruh Metodologi Tafsir Terhadap Hasil Tafsir QS. Al-Nisa: 03}

Perbedaan-perbedaan hasil tafsir Al-Qur'an oleh para mufassir umumnya disebabkan oleh perbedaan metode yang digunakan. Di antara metode peanfsiran adalah; Tablinhy (analisis); Ijmâly (gelobal); Muqârin (perbandingan); dan Maud̂̀'i (tematik). ${ }^{23}$ Sebanyak apapun literatur buku tafsir yang digunakan untuk memperolah penjelasan ayat Al-Qur'an akan sama hasilnya jika buku-buku tersebut mengunakan metodologi penafsiran yang sama.

Poligami dalam QS. Al-Nisa: 03 jelas menjadikan adil sebagai syarat uatama dengan lafadz أََََّعْدِلُوْا. Mustafâ al-Marâgî yang menggunakan metode tablîly atau analisis teks mensyaratkan dengan beberapa ketentuan seperti: 1) kemandulan isteri, 2) besarnya hasrat seks suami yang dimungkinkan isteri tidak bisa memenuhi, 3) kemampuan finasial suami untuk memenuhi kebutuhan isteri yang lebih dari satu dan anak-anaknya, serta 4) adanya ketimpangan sosial seperti banyaknya perempuan dan anak yatim yang dapat disejahterakan dan dilindungi dengan adanya poligami.

Al-Qurtûbî dalam al-Jâmi' li aḅkâm yang menggunakan metode tablîly yang dominan dengan ma'thûr periwayatan ayat-ayat merumuskan adil dalam pembagian kasih sayang, nafkah, persetubuhan, dan pergaulan. Rumusan tersebut mempunyai kesamaan dengan fikih dan undangundang.

Berbeda dengan Muhammad 'Alî al-Ṣâbûnî dalam Rawai'ul Bayân yang secara maudûi menganalisa surat QS. Al-Nisa: 03 dari Asbâb al-

\footnotetext{
${ }^{21}$ Muhammad Ibnu Qâsi al-Gâzî, Fațu al-Qarîb, (Surabaya: Al-Hidayah, 1992), 56.

22 Abdurrạ̣mân al-Juzairî, Fiqh 'Alâ al-Madzâabib al-Arba'ah...., 182.

${ }^{23}$ M. Quraish Shihab, Kaidab Tafsir....., 378
} 
Nuzûl-nya. Yaitu fenomena sahabat yang menjadi wali anak yatim dan kemudian menikahinya dengan tidak memebri nafkah. Mereka diperbolehkan menikahi dua, tiga dan empat wanita yang disukai namun harus berlaku adil. Asbâb al-Nuðûl ayat tersebutlah yang juga menjadi dasar berpolgami syaratnya adalah adil yang mencakup nafkah dan kemampuan memenuhi kebutuhan isteri dan anak-anak.

Berbeda dengan Al-Qurtûbî yang menggunakan tablilly dengan alma'thûr. Al-Zamakhsharî dalam Tafsîr al-Kashshâf menggunakan metode tafsir tablily bil al-ra'yi yang umumnya membahas aspek kebahasaan meliputi gramatika, semantik, sintaktis dan kesusastraanya. Menurut alZamakhsharî QS. Al-Nisa: 03 mempunyai orientasi sosial yaitu pembatasan jumlah isteri. Hal itu menjadi relevan karena dalam praktiknya tanpa ada rem laki-laki bisa beristeri lebih dari batasan yang ditentukan. Lebih lanjut dalam al-Kashshâf dijelaskan bahwa syarat utamanya adalah berlaku adil terhadap isteri-isterinya. Jika tidak monogami lebih baik. ${ }^{24}$

\section{Analisa Syarat Syah Poligami Dalam Undang-undang, Fikih dan Tafsir}

Di antara kewajiban warga negara adalah mentaati undang-undang yang berlaku. ${ }^{25}$ Contoh perundang-undangan tersebut adalah UU No.1 Tahun 1974, dan PP. No. 9 tahun 1975 yang mengatur tentang beristeri lebih dari satu.

Warga negara yang bermaksud poligami harus memenuhi prosedur hukum yang mencakup permohonan dan pembuktian kecakapan beristeri lebih dari satu. Tidak hanya itu, undang-undang juga memberi petunjuk teknis kepada Pengadilan dalam memeriksa kecakapan dari pemohon. Rincian dari kerja pengadilan dalam memeriksa pemohon poligami adalah:

Pertama, Ada atau tidak alasan berpoligami seperti; Isteri tidak menjalankan kewajiban; Isteri mendapat cacat badan; dan Isteri tidak dapat melahirkan keturunan.

Kedua, Ada atau tidaknya persetujuan isteri baik secara lisan maupun tulisan.

Ketiga, Ada atau tidaknya kemampuan suami untuk menjamin keperluan hidup isteri dan anak-anak yang dibuktikan dengan; Surat

\footnotetext{
${ }^{24}$ Muhammad Zamakhsarî, Tafsir Al-Kashshâf, (Beirut: Dâr al-Kutûb al-'Ilmiyah, 2006), Vol. I, 458

${ }^{25}$ Undang-undang Dasar 1945 Pasal 28 (j).
} 
keterangan penghasilan; Surat keterangan pajak penghasilan; surat keterangan lain yang dapat diterima oleh pengadilan.

Keempat, Jaminan suami berlaku adil yang dibuktikan dengan pernyataan dan janji yang ditetapkan untuk itu.

Aturan yang disebutkan dalam pasal 41 sampai dengan 45 adalah upaya mewujudkan syarat utama poligami yang semaksimal mungkin disesuaikan dengan Al-Qur'an ayat 3 yaitu al-'adâlah. Makna Adil dalam Al-Qur'an dalam perspektif undang-undang dibuktikan secara administrasi dengan pernyataan secara tertulis.

Selain itu ada uji kelayakan oleh pengadilan berupa pemeriksaan terhadap pemohon berupa adanya alasan poligami, persetujuan isteri, kemampuan memenuhi kebutuhan terhadap isteri dan anak, serta pernyataan berprilaku adil.

Substansi yang disebutkan dalam PP. No. 9 tahun 1975 pasal 41 sampai dengan 45 secara administratif dan tertulis telah memenuhi syarat utama poligami yaitu adil. Pembuktian mampu berlaku adil tersebut tertera dalam surat pernyataan yang berkekutan hukum karena ditandatangani di atas materai 6.000 .

Fikih sebagai rujukan pembuatan undang-undang yang berdasar pada hukum Islam menjelaskan sifat adil dengan tiga ketentuan yaitu; Adil dalam memberikan watku giliran kepada isteri; Adil atas tempat tinggal; dan Adil atas biaya hidup dan pakaian.

Penjelasan dalam literatur fikih yang mensyaratkan suami yang hendak poligami untuk berlaku adil dalam pembagian waktu giliran. Syarat tersebut direspon oleh Peraturan Pemerintah No. 9 tahun 1975 Pasal 41 bahwa kemampuan suami berlaku adil harus diawali dengan iktikad yang dibuktikan dengan pernyataan dan janji tertulis yang disepakati untuk itu.

Sementara syarat adil atas tempat tinggal dan biaya hidup dalam fikih juga disyaratkan dalam Peraturan Pemerintah Pasal 41. Yakni pemohon poligami harus membuat surat pernyataan penghasilan dan surat keterangan pajak penghasilan. Di mana dari kedua syarat tersebut pengadilan dapat menilai dan memutuskan layak dan tidaknya pemohon untuk berpoligami.

Sejatinya pandangan fikih dan undang-undang di atas adalah hasil ijtihad dari pernyataan QS. Al-Nisa: 03 sebagai induk hukum. Tafsir yang kedudukannya sebagai penjelas menjadi bahan dengar pembuatan undang-undang dan fatwa fikih yang variatif. Seperti syarat poligami yang dituturkan oleh al-Marâgî oleh dewan legislatif pembuat undang-undang diterjemahkan sebagai alasan-alasan berpoligami. 
Sementara mayoritas ulama fikih mengakomodir adil dengan tiga syarat yang kesemuanya mengarah kepada hal-hal yang bersifat material. Rumusan tersebut selaras dengan tafsir ayat 4 dan 29 QS. al-Nisâ'. Artinya, antara fikih, tafsir dan undang-undang sepakat menjadikan adil sebagai syarat utama berpoligami.

Bedanya tafsir dan fikih mensyaratkan poligami dengan norma, sedangkan undang-undang mensyaratkan norma-norma tersebut dipenuhi dengan data dan atau pernyataan tertulis yang berkekutan hukum. Jika telah dinilai kelayakan kemampuan pemohon oleh pengadilan sebagai seorang yang layak beristeri lebih dari satu maka keabsahan poligami yang dilakukan pemohon syah di hadapan hukum.

\section{Analisa Poligami Dalam Perspektif Feminisme}

Membincangkan kedudukan perempuan dan laki-laki selalu bersifat aktual, dinamis dan kerap menjadi polemik yang hangat di publik. Feminisme pada dasarnya adalah gerakan yang menuntut persamaan hak sepenuhnya antara laki-laki dan perempuan. Gerakan ini menyerukan equality perempaun dan laki-laki yang dalam Islam tidak bisa disederhanakan dengan pendekatan clear cut dichotomy.

Kesadaran tentang kesataraan tersebut diiringi oleh pemahaman keagamaan dan pengetahuan akan sejarah oleh kaum hawa yang terus membaik. Sehingga dalam perkembangannya kebutuhan untuk mereformasi pola relasi laki-laki perempuan menjadi urgen dan mengemuka.

Di Barat pada tahun 1960 dan 1970-an gerakan feminisme hampir mewarnai seluruh aspek kehidupan sosial seperti ekonomi dan kekuasaan politik. Bahkan diantaranya telah masuk ke dunia maskulin dan berkiprah selayaknya pria. Jika sebelumnya wanita kerap di stereotip-kan sebagai kaum inferior, sekarang bahkan telah dianggap superior. Feminimisme mempopulerkan agar kualitas kaum feminim terus meninggi dan tercipta keseimbangan hidup serta mencegah kerusakan. ${ }^{26}$

Pendekatan yang digunakan oleh aktivis feminimisme untuk memprioritaskan kualitas feminim adalah teori ecofeminsm. Ecofeminism mempunyai landasan filsafat gender yang disebut ecoshopy yang dengan tegas mengkritik peradaban Barat yang telah melampaui kapasitas dan menganggap kualitas maskulin dalam artian yang negatif. Filsafat ecoshopy dipengaruhi oleh spiritulitas ketimuran dan agama-agama mistik serta pola kehidupan orang-orang dahulu.

${ }^{26}$ Sachiko Murata, The Tao Of Islam......., 8

Tafaqquh-Volume 5, Nomor 1, Juni 2017 
Pada dua dekade terakhir bermunculan rumusan-rumusan teori yang menyoroti tentang posisi perempuan dalam kehidupan bermasyarakat. Tema besar yang diusung oleh teori-teori feminimisme tersebut adalah kritik terhadap sistem perkawinan patriarki yang memposisikan suami sebagai posisi vital pemegang otoritas utama.

Setidaknya ada tiga kelompok dalam pandangan feminimisme tentang kedudukan gender laki-laki dan perempuan yaitu: ${ }^{27}$

a. Feminimsme Liberal

Cloing pemikiran dari feminimisme liberal adalah manusia tercipta atas dasar keseimbangan baik laki-laki maupun perempuan. Seimbang dalam pandangan feminimisme liberal mempunyai simplikasi makna seimbang terwujud dengan keserasian dan tidak adanya tumpang tindih dan kekerasan.

Di antara pemikir-pemikir aliran feminimisme liberal adalah Anglina Grimke (1792-1873), Hariet Martineau (1802-1876), Susan Antony (1820-1906), dan Margaret Fuller (1810-1850). Pandanganpandangan mereka merujuk pada aspek filsafat ontologis yang dinamai sebagai prinsip-prinsip pencerahan seperti peryataan bahwa kekhususan-kekhususan pada hakikatnya sama-sama dimiliki oleh lakilaki dan perempuan.

Walaupun begitu dalam beberapa hal kelompok feminimisme liberal tetap berpandangan bahwa antara laki-laki dan perempuan harus ada pembedaan (distinction). Terutama yang menyangkut organ reproduksi yang berkonsekwensi terhadap peran perempuan di masyarakat.

Adapun tujuan dari gerakan feminimisme liberal adalah terciptanya kehidupan berimbang antara laki-laki dan perempuan yang bermanifestasi dalam keikutsertaan perempuan dalam semua peran kehidupan seperti sosial, ekonomi, budaya dan kekuasaan politik.

b. Feminimisme Marxis-Sosialis

Pemikiran feminimisme marxis-sosialis menyerukan pemerataan dengan tidak adanya kelas di masyarakat yang berdasarkan gender laki-laki dan perempuan. Aliran marxis-sosialis secara tegas menolak konsep-konsep budaya alam, biologis, dan latar belakang sejarah sebagai pijakan yang menurut mereka mendiskreditkan perempuan.

Tokoh besar feminimisme marxis-sosialis adalah Rosa Luxemburg (1871-1919) dan Clara Zetkin (1857-1933) yang mula-mula mengembangkan hasil pemikiranya di Jerman dan Rusia.

${ }^{27}$ Nasaruddin Umar, Argumen Kesetaraan Gender...., 68 
Teori feminimisme marxis-sosialis mempunyai kesamaan dengan teori konflik seperti menganggap perempuan sebagai kaum inferior yang dikembangkan dalam keluarga-keluarga kapitalis. Adapun yang menjadi fokus pemikiran yang berkaitan dengan ketimpangan gender menurut mereka adalah aplikasi dari sistem kapitalis di dalam rumah tangga dimana tidak adanya upah bagi pekerja perempuan.

Lebih lanjut aliran ini mensoroti sistem perkawinan patriarki dengan tidak men-dikotomi sektor pekerjaan antara laki-laki dan perempuan baik dalam skala domestik maupun publik. Adapun perbedaan teori Marxis-Engels feminimisme dengan teori konflik adalah pada objek fokus bahasanya. Teori konflik membicarakan akumulasi modal yang berimbas pada kepemilikan harta pribadi. Sementara dalam perspektif Marxis-Engels yang dikaji adalah kesetaraan gender dan kedudukan seksualitas.

c. Feminimisme Radikal

Kelompok feminimisme radikal secara terang-terangan menggugat seluruh institusi yang dalam pandanganya telah merugikan perempuan pada abad ke-19. Di antara pemikiran aliran feminimisme liberal yang menjadi polemik adalah adanya tuntutan hak yang dibarengi dengan kesamaan dalam kepuasan seks. Implikasi dari pandangan tersebut adalah pemberian legalitas kepuasan seksual dari sesama perempuan dengan mentolerir praktik lesbian.

Feminimisme radikal menyatakan bahwa laki-laki adalah masalah bagi perempuan. Mereka, laki-laki telah mengeksploitasi perempuan teutama yang berhubungan dengan alat reproduksi dan fenomena tersebut telah terjadi sepanjang sejarah serta berlarut-larut. Sehingga dalam pandangan feminimisme radikal tidak cukup aturan dan perundang-undangan namun harus ada gerakan yang secara mendasar menyerukan ketimpangan gender tesebut.

Aliran feminimisme radikal termasuk aliran feminimisme paling kontroversial dengan pandangan bahwa laki-laki dan perempuan sama secara total. Pendapat tersebut kontras dan mendapatkan krikitikan dari sosiolog dan bahkan dari kalangan feminimisme sendiri dengan antitesis pemerataan antara laki-laki dan perempuan hanya akan mensulitkan perempuan sendiri di mana laki-laki yang tanpa organ biologis seperti perempuan akan sulit diimbangi. 
Beberapa pandangan tokoh feminimisme: ${ }^{28}$

a. Dona Haraway

Memiliki pandangan bahwa menjadi perempuan harus bisa menolak eksploitasi dan hegemoni dari laki-laki dengan mengidentifikasi dirinya dengan kecanggihan teknologi. Pendapat Dona Haraway ini, yang mendorong dirinya melakukan cyborg yaitu trasnformasi pasca gender setelah melakukan proses pencangkokan mesin dan organisme.

b. Luce Irigarai

Pemikiran Luce Irigarai menyatakan perempuan adalah laki-laki yang ter-kastrasi atau laki-laki yang dikebiri. Deskripsi pemikiran Irigarai adalah perempuan harus membentuk citra dirinya sendiri dengan cara yang berbeda dari kaum laki-laki. Irigarai memetakkan pemikirannya yang terfokus pada organ biologis dengan berkutat pada vagina, penis, klitoris, dan organ seks lainya.

c. Hellene Cixous

Pemikir yang juga novelis, penulis drama dan kritikus feminimisme ini memberikan kritik penggunaan kata feminim yang dikaitkan dengan tubuh. Konsekuensinya adalah ketika menyebut feminim maka identifikasinya akan mengarah pada fiskal yang mematerisasikan perempuan.

Secara umum gerakan feminimisme di dunia menyerukan keadilan, kesamaan dan kesetaraan hak dan kewajiban antara laki-laki dan perempuan. Amina Wadud Muhsin, seorang tokoh feminimis muslimah asal Amerika Serikat yang gaya penafsirannya dipengaruhi oleh pemikiran Fazlur Rahman melakukan metode tafsir dengan konsep kontekstual.

Di antara pandangan Fazlur yang diikuti Amina adalah ungkapan bahwa wahyu yang diturunkan kepada nabi mengandung dua sisi yang dapat dipetakan. Yaitu keadaan turunya yang bersifat umum dan yang bersifat khusus. Implikasi ungkapan ini, menjadikan Al-Qur'an tidak bisa direduksi dan tidak terbatas pada situasi historis ketika diwahyukan saja.

Wadud mengembangkan metode tafsir tauhid yang memposisikan kerangka berpikir sistematis yang dikolerasikan dengan aspek-aspek universal dan dinamika-dinamika sosial dengan pertalian berdasar AlQur'an. Selanjutnya untuk memahami kandungan ayat dipakailah kajian pembentukan Al-Qur'an baik secara linguistik, gramatika, dan simantiknya.

28 http://webcache.googleusercontent.com/search?q=cache:http://galeryfeminis. blogspot.com/2009/05/tokoh-tokoh-feminis-dan-teori-teorinya.html 
Praktik dari cara berpikir Wadud dalam hal penggunaan legitimasi superioritas laki-laki atas perempuan dapat dilihat bahwa ia menarik akar masalah yang bersifat teologis seperti Surat al-Rûm [31]: 21 dan al-Nisâ' [4]: 1 yang menyuarakan asa-usul kejadian manusia dan kesamaankesamaanya.

Pandangan gender oleh Amina dimulai dari kata nafs dan zawj yang menurutnya sesungguhnya tidak ada deskriminasi antara penciptaan lakilaki (maskulin) dan perempuan (feminin). Bahkan ia mengkritisi pendapat mufassirin yang mempertentangkan dua kata tersebut dengan memberikan sanggahan bahwa nafs sebenarnya tidak menunjukkan pengkhususan diri melainkan bersifat umum. Berangkat dari sinilah wadud mengembangkan konsep balancing power di mana antara laki-laki dan perempuan mempunyai kedudukan sama ibarat dua sayap merpati yang bertujuan menggerakkan dan membawa terbang tubuh merpati.

Sedangkan untuk merespon konsep keadilan dalam poligami Wadud menegaskan bahwa pada hakikatnya cita-cita Al-Qur'an adalah pernikahan yang berasas poligami. Adapaun poligami yang dituturkan dalam surat QS. Al-Nisa: 03 tertuju pada kewajiban muslim untuk mensejahterakan anak yatim baik dalam pengasuhan, dan pemeliharaan harta.

Aminah berpendapat keadilan dalam poligami tidak dapat diraih dengan ukuran persamaan kasih sayang, kualitas waktu, dan dukungan yang bersifat moral, spiritual dan intelektual ketika seorang suami atau ayah mempunyai dua keluarga.

Berbeda dengan Aminah, Qâsim Amîn mengidentifikasi poligami sebagai produk adat istiadat kuno yang dirubah oleh Islam dan telah bermanifestasi di negara-negara muslim. Qâsim Amîn mempunyai pendapat bahwa dalam poligami ada penghinaan terhadap wanita yaitu pada hakikatnya tidak ada perempuan yang mau dimadu seperti rasionalitas ketika seorang laki-laki marah ketika perempuanya dicintai oleh laki-laki lain.

Dasar pijakan antara Wadud dan Qâsim serta jumhur ulama adalah sama yakni QS. al-Nisâ': 3. Di mana ayat tersebut diturunkan setelah terjadi Perang Uhud yang menyebabkan banyak pejuang Islam gugur, banyak janda dan anak yatim yang ditinggal wafat oleh ayah-ayahnya.

Penulis berpendapat poligami tetap relevan untuk dikembangkan di nagara-negara muslim. Dalam artian tidak dipropagandakan secara publik siapapun bisa melakukan poligami. Namun adanya pembatasan ruang lingkup poligami dengan persyaratan yang patut dan layak. Kepatutan 
dan kelayakan yang dimaksud di sini adalah syarat perimer berpoligami yaitu keadilan terhadap isteri-isterinya.

Poligami telah memenuhi kelayakan dan kepatutan secara obyektif dapat dibuktikan dengan izin yang diperoleh dari isteri. Izin dari isteri untuk berpoligami ini juga dapat menolak risiko subjektifitas poligami yang dikhawatirkan hanya dimanfaatkan sebagai suprioritas suami dan deskriminasi atas perempuan.

Umumnya negara-negara Islam yang telah mengakomodasi poligami dalam perundangan telah mempertimbangkan kasuistik latar belakang turunya QS. al-Nisâ': 3. Juga telah membaca pendapat-pendapat ulama dan mufassir tentang legitimasi poligami oleh Islam. Sehingga tidak bijak ketika kita menutup mata adanya poligami yang telah disyariatkan dalam Islam dengan tidak mengakomodasikannya dalam perundangan.

Adapun kekhawatiran ketidakadilan ketika suami melakukan poligami menurut penulis sesungguhnya telah diresolusi dengan persyaratan yang ketat ketika akan melakukan poligami. Sebagai contoh di Indonesia yang mayoritas penduduknya muslim dan menjadi negara dengan penduduk muslim terbesar dunia telah mengatur poligami dalam Undang-Undang Tentang Perkawinan No. 1 Tahun 1974. Di mana dalam undang-undang tersebut secara ketat mensyaratkan laki-laki yang ingin mengawini wanita lebih dari satu harus mendapatkan izin dari isteri, melampirkan slip gaji dan pembayaran pajak dan surat pernyataan kesanggupan berlaku adil.

Demikian menurut penulis, poligami harus tetap diakomodasi karena syariat telah mengaturnya dan terdapat nasss yang menjadi legitimasi hukum. Namun dalam penerapan teksnisnya harus ada ijtihad-ijtihad kreatif yang sesuai dengan situasi sosial di mana poligami diundangkan. Jika telah memenuhi syaratnya, atau bahkan dalam taraf butuh untuk poligami, jadi kenapa tidak melakukan poligami? 


\section{Kesimpulan}

Pertama, tafsir QS. al-Nisâ' ayat 3 pada dasarnya membicarakan tentang prinsip perkawinan monogami dan syarat untuk melakukukan poligami. Suami tidak diizinkan melakukan poligami jika masih khawatir tidak dapat berbuat adil. Merujuk pada lafadz shartiyyah وَاِنْ خِفْتُم yang juga

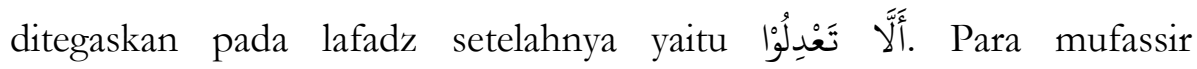
mensyaratkan keabsahan poligami yang tercantum dalam QS. al-Nisâ' ayat 3 jika suami bisa berbuat adil.

Kedua, Satu-satunya syarat keabsahan poligami di dalam surat al-Nisa ayat 3 adalah berlaku adil dengan penegasan lafa memberi ukuran yang bervariatif terhadap lafaz adil pada ayat tersebut. Diantara pendapat yang selektif secara yuridis formil membuktikan suami bisa adil atau tidak adalah Imam al-Marâgî dengan tambahan syarat apabila (1) isteri mandul. (2) Suami memiliki hasrat seks yang tinggi, dan isteri tidak mampu melayani suami tersebut. (3) Suami memiliki harta yang cukup untuk membiayai semua kebutuhan keluarga, yang mencakup kebutuhan isteri dan anak-anak. Dan (4) Jika jumlah wanita lebih banyak daripada pria, yang mungkin terjadi akibat perang, yang menyebabkan banyaknya janda dan anak yatim yang perlu untuk dilindungi. 


\section{Daftar Pustaka}

Al-Qur'an.

Anșârî (al), Zakariyya. Faț al-Wahhâh. Beirut: Dâr al-Fikr, 2008.

Bajûrî (al), Ibrâhîm. Hâashiyah al-Bajûrî. Beirut: Dâr al-Kutûb al-'Ilmiyah, 2015. Vol. II.

Bakrî (al), Muhammad Shạtâ al-Dimyạtî. I'ânat al-Ṭâlibîn. Beirut: Dâr alKutûb al-'Tlmiyah, 2006.

Gâzî (al), Muhammad Ibnu Qâsi. Fatḥu al-Qarîb. Surabaya: al-Hidayah, 1992.

Hịâzî, Abdullâh bin. Hashiyah al-Sharqâmî. Beirut: Dâr al-Kutub al'Ilmiyah, 2005. Vol. IV.

Juzairî (al), Abdurrahmôn. Fiqh 'Alâ al-Madhâhib al-Arba'ah. t.t.

Juzairî (al), Abdurraḥmân. Fiqh 'Alâ al-Madzâabib al-Arba'ah. Beirut: Dâr al-Fikr, 2008. Vol. IV.

Malibarî (al), Zainuddîn bin 'Abdu al-'Azîz. Fathu al-Mu'în. Surabaya: alHidayah, 1993.

Marâgî (al), Muștafâ. Tafsîr al-Marâgî. Mesir: t.t.p, 1974. Vol. IV.

Qựtûbî (al), Muhammad al-Aṇ̦arî. Al-Jâmi' li Aḅkâm al-Qư'ân. Beirut: Dâr Iḥya' al-Turâth al-'Arabî, 2002.

Sâbûnî (al), Muhammad 'Ali. Rawai'u al-Bayân. Jakarta: Dâr al-Kutûb alIslâmiyyah, 1999. Vol. I.

Shihab, M. Quraish. Kaidah Tafsir. Tangerang: Lentera Hati, 2013. - Tafsir al-Misbab; Pesan, Kesan dan keserasian al-Qur'an. Jakarta: Lentera Hati, 2006. Vol. II.

Shihab, M. Quraish. Wawasan Al-Qur'an. Bandung: Mizan, 1999.

Zamakhsarî, Muhammad. Tafsîr al-Kashshâf. Beirut: Dâr al-Kutûb al'Ilmiyah, 2006. Vol. I. 